\title{
Endocrine Disruption, Cytotoxicity and Genotoxicity of an Organophosphorus Insecticide
}

\author{
Afifa Belaid ${ }^{1}$, Nosra Methneni ${ }^{1}$, Emna Nasri ${ }^{1}$, Sarra Bchir ${ }^{1}$, Roel Anthonissen ${ }^{2}$, Luc Verschaeve ${ }^{2}$, \\ Véronique Le Tilly ${ }^{3}$, Vincenzo Lo Turco ${ }^{4}$ (D), Giuseppa Di Bella ${ }^{4}$, Hedi Ben Mansour ${ }^{1, *(D)}$ \\ and Nezar H. Khdary $5, *$ (D)
}

1 Research Unit of Analysis and Process Applied to the Environment, Higher Institute of Applied Sciences and Technology, Mahdia 5100, Tunisia; afifa.belaid@gmail.com (A.B.); methneninosra28@gmail.com (N.M.); emmna.nasri@gmail.com (E.N.); sarra.bchir@yahoo.fr (S.B.)

2 Scientific Direction Chemical and Physical Health Risks, Sciensano, 1050 Brussels, Belgium; Roel.Anthonissen@sciensano.be (R.A.); Luc.Verschaeve@sciensano.be (L.V.)

3 IRDL FRE CNRS 3744, Université Bretagne Sud, 56100 Lorient, France; veronique.le-tilly@univ-ubs.fr

4 BioMorf Department, University of Messina, 98168 Messina, Italy; vincenzo.loturco@unime.it (V.L.T.); giuseppa.dibella@unime.it (G.D.B.)

5 King Abdulaziz City for Science and Technology (KACST), Riyadh 11442, Saudi Arabia

* Correspondence: hdbenmansour@gmail.com (H.B.M.); nkhdary@kacst.edu.sa (N.H.K.)

check for

updates

Citation: Belaid, A.; Methneni, N.; Nasri, E.; Bchir, S.; Anthonissen, R.; Verschaeve, L.; Le Tilly, V.; Lo Turco, V.; Di Bella, G.; Ben Mansour, H.; et al. Endocrine Disruption, Cytotoxicity and Genotoxicity of an Organophosphorus Insecticide. Sustainability 2021, 13, 11512.

https://doi.org/10.3390/su132011512

Academic Editor: P. Senthil Kumar

Received: 28 August 2021

Accepted: 1 October 2021

Published: 18 October 2021

Publisher's Note: MDPI stays neutral with regard to jurisdictional claims in published maps and institutional affiliations.

Copyright: (c) 2021 by the authors. Licensee MDPI, Basel, Switzerland. This article is an open access article distributed under the terms and conditions of the Creative Commons Attribution (CC BY) license (https:/ / creativecommons.org/licenses/by/ $4.0 /)$.

\begin{abstract}
In the present study, a battery of biological tests undertaken in vitro and in vivo was used to evaluate the toxic potential of an organophosphorus insecticide, namely Fenitrothion. The cytotoxic effect of pesticide was evaluated with the MTT assay against two human cancer cell lines: Hep-2 and MDA-MB-231. Genotoxicity was also studied using the bacterial VITOTOX ${ }^{\circledR}$ assay. The estrogenic effect was tested using the recombinant yeasts (YES) assay. Likewise, bioluminescence assays using $V$. fischeri and D. magna immobilization were performed. The results showed that Fenitrothion exhibits a variable cytotoxic effect depending on the dose as well as the studied cell lines, and no genotoxicity was observed in the tested sample. However, an estrogenic effect was recorded when investigating Fenitrothion using the recombinant yeasts (YES) assay. Analogously, acute toxicity was observed for both organisms and at all tested concentrations of Fenitrothion. Overall, these results underline the crucial importance of in vitro and in vivo bioassays in monitoring toxicity of pesticides.
\end{abstract}

Keywords: fenitrothion; bioassays; cytotoxicity; genotoxicity; estrogenicity; ecotoxicity

\section{Introduction}

Organophosphorus substances (OPs) are the most widely used insecticides worldwide. The OPs also constitute a major group of chemical warfare agents which continue to pose a global human health threat [1].

Fenitrothion [O,Odimethyl-O-(3-methyl-4-nitrophenyl) phosphorothioate] is an OPs that has several uses in agriculture [2]. This pesticide is mainly used to control the detrimental effect of insects on rice, cereals, fruits, vegetables, stored grains and cotton. It is also currently used for mosquito control [3]. The total world production of Fenitrothion is estimated to be approximately 15,000-20,000 tons annually. Field doses can exceed $500 \mathrm{~g} /$ ha because of the average concentrations of $80 \mu \mathrm{g} / \mathrm{L}$ in the treated water body [4].

Fenitrothion, like all pesticides, acts chemically on effectors that are often involved in vital functions or in reproduction. It disrupts the nerve or the hormonal signaling, the cellular respiration, the cell division or the protein synthesis, thus allowing effective control of the pest organism [5]. It is true that the pesticide is always toxic to the target for which it has been developed but it might not be very specific to a pest organism because of the partially common physiological processes and mechanisms of organisms. As a result, a pesticide, which is intended to control a pest organism, has a more or less extensive 
toxicological potential on the other organisms that were not targeted at first. The pesticide professional users or the common individuals are therefore possibly at risk of the improper use of the pesticides which inevitably can cause health problems within hours or days.

These health risks or disorders are developed just like the pesticide mechanisms whilst acting against the pest [5]. Several studies show that human exposure to Fenitrothion could promote the development of neurological [6], immunological [7] and reproductive disorders [8]. More recently, a study in Tunisia was conducted on pesticide handlers showed a decrease in serum and globular cholinesterase activity along with Fenitrothion detection among workers [9].

Fenitrothion also poses a risk on other "non-targeted" organisms including aquatic organisms. This pesticide is classified as highly toxic to aquatic organisms. However, we found that the use of biomarkers is a relevant tool used in signalling the biological signature of the impact or the presence of any contaminant in a living structure. In order to study the ecotoxicological risk associated with the use of Fenitrothion, we tried to determine its toxicity on humans and animals as well as its particular ability to concentrate in the ecosystems as one of the major polluting pesticides.

The type of pollution that affects low-volatility, soil-infiltration and that results from water-dense pesticides is remarkably dangerous. In fact, water pesticides can contaminate groundwater and drinking water for long periods of time when accumulated in highly concentrated levels. In this context, several studies have demonstrated the presence of Fenitrothion residues in various parts of the environment (water, sediment, food, etc.) $[10,11]$ and the potential risk of bioaccumulation in trophic chains as well.

It is within this framework that our research focused on the following objectives.

a. To evaluate the impact of Fenitrothion on the metabolism of two cell lines: Hep-2 and MDA-MB-231.

b. To assess the genotoxicity and estrogenicity of this pesticide using the VITOTOX ${ }^{\circledR}$ test and the YES assay.

c. To evaluate its estrogenic potential using two organisms: the Vibrio fischeri and the Daphnia magna, belonging to different trophic levels.

\section{Materials and Methods}

\subsection{Chemicals}

The purity of each compound ranges from 95.2 to $99.6 \%$ according to the manufacturer's specifications. The pesticide Fenitrothion (CAS No. 122-14-5), Dulbecco's modified Eagle's medium (DMEM), L-glutamine, Dimethyl sulfoxide (DMSO), Penicillin and Streptomycin, Phosphate buffer saline (PBS), Trypsin-EDTA, fetal calf serum (FCS) and the sterile material used for culture (flasks and culture plates) were from Dutscher (Bernolsheim, France). The unspecified chemicals were purchased from Sigma-Aldrich (St. Quentin Fallavier, France).

\subsection{Cell Culture}

To study the antiproliferative effect of the pesticide, we used two tumor cell lines, namely: the $90 \mathrm{Hep}-2$ cell line represented by human epidermoid cancer cells [10] considered to originate 91 from a carcinoma of the human larynx [11] and the MDA-MB-231 cell line which is 92 commonly used for the development of new therapeutic approaches in breast cancer [12]. Cells were obtained from the American Type Culture Collection (ATCC, USA) and were cultured in a humidified atmosphere of $5 \% \mathrm{CO}_{2}$ and $95 \%$ air at $37^{\circ} \mathrm{C}$. The culture medium (DMEM) was supplemented with $1 \%$ L-glutamine, $1 \%$ Penicillin/Streptomycin and 10\% (for cell multiplication) or 2\% (for cell maintenance) heat inactivated $\left(56{ }^{\circ} \mathrm{C}, 30 \mathrm{~min}\right)$ fetal calf serum (FCS). When the cell culture reached $80 \%$ confluence, cells were dispersed with $0.025 \mathrm{M}$ trypsin-EDTA and reseeded in new flasks. The passage number of the cells used in the experiments was between 10 and 25, and the culture medium was replaced every $48 \mathrm{~h}$. 


\subsection{Choice of Fenitrothion Concentrations}

Fenitrothion was used at concentrations between 50 and $400 \mu \mathrm{M}$. The concentrations used in this study were selected on the basis of data on pesticides in the form of residues in food, as well as on the basis of maximum residue limits (MRLs) [13] with a simple adjustment. Upon receipt, the pesticide was dissolved in sterile distilled water and stored as stock concentration of $800 \mu \mathrm{M}$ at $-20^{\circ} \mathrm{C}$. Each aliquot was thawed and used only once.

\subsection{Evaluation of Cell Viability by MTT Assay}

The 3-(4, 5-dimethylthiazol-2-yl)-2, 5-diphenyl tetrazolium bromide (MTT) colorimetric assay was used to check the toxicity of Fenitrothion on Hep-2 and MDA-MB-231 cell lines. This analysis was used to investigate the metabolic activity of the cells since it allows the determination of the mitochondrial function of cells by measuring the activity of mitochondrial succinate dehydrogenase enzyme, which cleaves MTT into a blue colored product (formazan). Briefly, both cell lines were seeded in 96-well plates (at a rate of $5 \times 10^{5}$ cells $/ \mathrm{mL}$ for Hep-2 cells and $2 \times 10^{5}$ cells $/ \mathrm{mL}$ for MDA-MB-231 cells) and incubated during $24 \mathrm{~h}$ to ensure adequate adhesion of cells. From a Fenitrothion stock solution $(800 \mu \mathrm{M})$, a series of dilutions was made in the maintenance medium ( $2 \%$ heatinactivated FCS) to obtain the following concentrations: 400, 200, 100, $50 \mu \mathrm{M}$. The growth medium was replaced with different concentrations of Fenitrothion in triplicate, at the rate of $200 \mu \mathrm{L} /$ well. A control without treatment was carried out by adding $200 \mu \mathrm{L}$ of the maintenance medium. After $24 \mathrm{~h}$ of toxicant exposure, the culture medium was discarded and $100 \mu \mathrm{L}$ of MTT reagent $(0.5 \mathrm{mg} / \mathrm{mL})$ was added to each well. Following incubation for $3 \mathrm{~h}$, each well received $100 \mu \mathrm{L}$ of DMSO in order to completely dissolve the formazan crystals. Afterward, the absorbance was detected at $570 \mathrm{~nm}$. All tests were performed along two independent experiments.

The results represent the means of the median values obtained and are calculated as a percentage of cell viability relative to the control condition (cells without treatment).

The viability and toxicity percentages were calculated according to the following formulas [14] as follows:

$$
\begin{gathered}
\% \text { viability }=[\text { OD570 } \mathrm{nm} \text { treated cells } / \text { OD570 } \mathrm{nm} \text { control cells }] \times 100 \\
\text { Cytotoxicity }(\%)=100-\text { viability }(\%)
\end{gathered}
$$

\subsection{Genotoxicity Assessment}

The VITOTOX ${ }^{\circledR}$ test was conducted to screen the cytotoxic and the genotoxic potential of Fenitrothion. This test, based on the SOS DNA-repair system, makes use of two genetically engineered bacterial strains: Salmonella typhimurium strains TA104 pr1 (Cytox strain) and TA104 recN2-4 (Genox strain). They are used as porter systems for genotoxicity and cytotoxicity [15]. The referred protocol was the Vitotox-10 manual of Gentaur (Kampenhout, BE) as it was previously outlined. In 96-well plates, four concentrations of Fenitrothion $(0,0.25,0.5$ and $1 \mathrm{mM})$ and positive/negative control substances were prepared. Positive controls were benzo $(\alpha)$ pyrene in the presence of S9 and 4-nitroquinoline-oxide (4-NQO) in the absence of S9. Methanol was used as the negative control. The tests were carried out in the absence and in the presence of a rat metabolic enzymatic fraction (S9) in order to test the genotoxic potential of pure molecules and its metabolites. The genotoxicity and the toxicity measurements were carried out using a luminometer (GloMax ${ }^{\circledR}$, Promega Benelux bv, Leiden, Nederland) which allows online measurements of the light emitted every $5 \mathrm{~min}$ during $4 \mathrm{~h}$. After the measurements were completed, the signal-to-noise $(\mathrm{S} / \mathrm{N})$ ratio, i.e., the light output of the exposed bacteria divided by the light output of the unexposed bacteria, was calculated. A compound is considered genotoxic when the max $\mathrm{S} / \mathrm{N}$ Genox/max S/N Cytox ratio is greater than 1.5 [15]. 


\subsection{Estrogenic Activity Assessment}

The Yeast Estrogen Screen (YES) assay was used in our study to elucidate the estrogenic activity of fenitrothion. In this assay, recombinant yeast cells "Saccharomyces cerevisiae" were transformed with an expression of plasmid containing a gene encoding the human estrogen receptor-alpha $(\mathrm{hER} \alpha)$ and a plasmid containing the estrogen-responsive element and carrying the reporter gene lac- $Z$ coding for $\beta$-galactosidase [16]. Upon activation of the hER receptor, $\beta$-galactosidase was secreted in the medium which catalysed the hydrolysis of the colorless substrate o-nitrophenyl- $\beta$-D-galactopyranoside (ONPG) into a yellow product quantifiable by spectrophotometry.

The YES assay was performed according to Le Grand et al. [17] method. Yeast cells Saccharomyces cerevisiae were transformed with an inducible plasmid pY60her $\alpha$ containing a gene encoding human estrogen receptor-alpha $(\mathrm{hER} \alpha)$ and an expression plasmid YRPE2 encompassing the reporter gene lac- $Z$ coding for the enzyme $\beta$-galactosidase.

Transformed yeast cells were grown overnight in a selective medium $(6.7 \mathrm{~g} / \mathrm{L}$ nitrogen base without amino acids, $\mathrm{pH} 5.8,20 \mathrm{~g} / \mathrm{L}$ glucose, plus dropout supplements: DO-ura-leu). Afterward, this preculture was diluted in a rich medium (YPRE, $20 \mathrm{~g} / \mathrm{L}$ tryptone, $10 \mathrm{~g} / \mathrm{L}$ yeast extract, $10 \mathrm{~g} / \mathrm{L}$ raffinose, $\mathrm{pH} 7.0$ and $1 \%$ ethanol) so that an $\mathrm{OD}_{600 \mathrm{~nm}, l=1 \mathrm{~cm}}=0.1$. When $\mathrm{OD}_{600 \mathrm{~nm}, l=1 \mathrm{~cm}}$ reached $0.4, \mathrm{hER} \alpha$ expression was induced by $20 \mathrm{~g} / \mathrm{L}$ galactose.

Yeast cultures $(1 \mathrm{~mL})$ from an overnight induction were dispensed into 24-well plates and exposed to different concentrations of Fenitrothion. Assay plates were incubated at $30{ }^{\circ} \mathrm{C}, 150 \mathrm{rpm}$. In each test plate, a positive control (17-beta-estradiol (E2) with an initial concentration of $2 \times 10^{-8} \mathrm{M}$ ) and negative control (methanol) were included.

After $3.5 \mathrm{~h}$ of stimulation, the $\beta$-galactosidase activities were monitored. Plates were suspended again in $1 \mathrm{~mL}$ of Z-buffer $\left(60 \mathrm{mM} \mathrm{Na}_{2} \mathrm{HPO}_{4}, 40 \mathrm{mM} \mathrm{NaH}_{2} \mathrm{PO}_{4}, 10 \mathrm{mM} \mathrm{KCl}\right.$, $1 \mathrm{mM} \mathrm{MgSO}_{4}, \mathrm{pH} 7.0$ and $50 \mathrm{mM} \beta$-mercaptoethanol). From this cell suspension, 10 times diluted suspensions were prepared in triplicate. A volume of $250 \mu \mathrm{L}$ of diluted suspension was transferred in a black 96-well-plate and plates were checked for absorbance at $600 \mathrm{~nm}$ in a microtiter plate reader to determine yeast concentration.

The remaining volume was used to monitor $\beta$-galactosidase activities. To this end, yeast cells were reconstituted in 1/20 (v/v) volume of acetone:toluene (9:1) for $15 \mathrm{~min}$ at $30^{\circ} \mathrm{C}$; then, chromogenic reaction was started with an addition of ONPG $(4 \mathrm{mg} / \mathrm{mL})$ and terminated by the addition of $0.3 \mathrm{~mol} / \mathrm{L} \mathrm{Na}_{2} \mathrm{CO}_{3}$ when the color of solution became yellow. After centrifugation (11,700 $\mathrm{g}$ for $1 \mathrm{~min})$, the OD $420 \mathrm{~nm}, l=1 \mathrm{~cm}$ values of the supernatant were monitored, and $\beta$-galactosidase activity (Activity) was expressed in Miller units according to Miller Equation (1) [18]:

$$
\beta \text {-galactosidase activity (Miller units) }=\frac{1000 \times \text { OD420nm, } l=1 \mathrm{~cm}}{t \times v \times \text { OD600nm, } l=1 \mathrm{~cm}}
$$

where $(t)$ is the reaction time $(\mathrm{min})$ and $(v)$ is the volume of the cell suspension $(0.1 \mathrm{~mL})$.

The data of the dose-response curves were fitted according to the Hill Equation (2) by using Ligma Plot software:

$$
\text { Activity }=\text { Activity }_{[L] \rightarrow 0}+\frac{a \times[L]^{n}}{E C_{50}+[L]^{n}}
$$

For each compound and tested product, the displayed results were expressed in terms of the estrogenic activity. This is calculated with the following Equation (3):

$$
\beta \text { - } \text { galactosidase relative activity }=\frac{\text { Activity }_{[L]}-\text { Activity }_{[L] \rightarrow 0}}{\text { Activity }_{[E 2] \max }-\text { Activity }_{[L] \rightarrow 0}}
$$

where $[E 2]_{\max }$ corresponds to the required $17 \beta$-estradiol concentration for maximal activity. 


\subsection{Ecotoxicity Investigation}

\subsubsection{Daphnia magna Assay}

In order to assess the potential toxicity of Fenitrothion, we selected Daphnia magna as one of the species to be exposed. D. magna acute toxicity tests were performed according to the ISO 6341 guideline.

First, an artificial freshwater medium was prepared according to Molins-Delgado et al. [19] by adding $10 \mathrm{~mL}$ of four different saline solutions containing the needed salts and deionised water up to a volume of $2 \mathrm{~L}$. A series of vessels containing $10 \mathrm{~mL}$ of oxygenated medium together with the selected chemical were prepared along with a series of blank control solutions containing only culture medium. Acute toxicity tests were conducted in accordance with [19]. Neonates ( $<24 \mathrm{~h}$ old) in groups of 20 were transferred directly using a disposable Pasteur pipette from the vessels to a Petri dish $(10 \mathrm{~mL})$. The animals were exposed to six concentrations of Fenitrothion: $3 \%, 6 \%, 12 \%, 25 \%, 50 \%$, and $100 \%$. ASTM hard water (ASTM standards used in the production and testing of personal protective equipment) was used as a diluent. Petri dishes were illuminated with a constant light (3000 lux) and kept at $22{ }^{\circ} \mathrm{C}$. The number of immobilized neonates in each vessel was counted using a stereomicroscope. The number of immobilized neonates was correlated to the concentration of Fenitrothion allowing the determination of the 24 and $48-\mathrm{LC}_{50}$ values. Two bioassays proportions were carried out, with two replicates.

\subsubsection{Vibrio fischeri Assay}

$V$. fischeri's acute toxicity test was conducted based on the ISO 11348-3 guideline. Each sample was tested in duplicate. A culture medium was prepared consisting of water with $3 \% \mathrm{NaCl}$. Standard solutions of the target compounds were prepared at different concentrations in the culture medium Aliivibrio fischeri $\left(\mathrm{ATCC}^{\circledR} 7744^{\mathrm{TM}}\right.$ ). Vials containing the bacteria were stored at $20^{\circ} \mathrm{C}$ prior to analysis. The analyzer, controlled by the software Microtox Omni (SDI), was equipped with a 30-well temperature-controlled incubator chamber, which was set to $15{ }^{\circ} \mathrm{C}$. In each well, a cell containing culture medium was introduced. The vial with the bacteria was then reconstituted with $5 \mathrm{~mL}$ of a saline solution provided by SDI and transferred into a well inside a cell. A few minutes before starting the test, $20 \mathrm{~mL}$ of the solution containing the bacteria was added to each cell. After 15 and $30 \mathrm{~min}$, photometric measures of each cell were taken in the analyzer. The recorded absorbance values were then correlated with the different concentrations of Fenitrothion to estimate the 15 and 30 min $\mathrm{EC}_{50}$ values.

\subsubsection{Acute Toxicity Evaluation}

(a) Daphnia magna

The percentage of inhibition (I) was calculated following Equation (4) and related to the different concentrations of Fenitrothion using the Hill regression model of Equation (4) and the curve fitting tools of the Graph Pad Prism software:

$$
I=\frac{D_{i}}{D_{0}} \times 100
$$

where $D_{0}$ is the number of initial neonates and $D_{i}$ is the number of immobilized ones:

In order to correlate the incidence rates estimated with the concentrations of the chemicals, Equation (5) was applied:

$$
I=B+\frac{(T-B)}{\left(1+10^{\left(\left(\log E C_{50}-X\right) \times H\right)}\right)}
$$

where $T$ is the top value of the curve, $B$ is the bottom parameter of the curve, $\log E C_{50}$ is the logarithm of the median effect concentration, $X$ is the logarithm of the compound concentration, and $H$ is the Hill coefficient of the curve. The $E C_{50}$ values were further calculated for the algae using this equation. 


\section{(b) Vibrio fischeri}

The bioluminescence was determined by the absorbance measurements, and then Equation (6) was applied to estimate the incidence rates:

$$
I=\frac{\mathrm{ABS}_{0}-\mathrm{ABS}_{t}}{\mathrm{ABS}_{t}}
$$

where $I$ is the percentage of inhibition, $\mathrm{ABS}_{t}$ is the absorbance at the time of the analysis, and $\mathrm{ABS}_{0}$ is the initial absorbance. Inhibition rates were then correlated with different Fenitrothion concentrations. Toxicity was estimated by calculating the Toxicity Units (TU) according to Equation (7) as described by Tamura et al. [20].

$$
\mathrm{TU}=100 / \mathrm{ECx}
$$

where $\mathrm{ECx}$ is the $\mathrm{X} \%$ effect concentration of Fenitrothion. A value of $\mathrm{TU}<1$ indicates a nontoxic effect, whereas a value of $\mathrm{TU}>1$ corresponds to a toxic effect.

\section{Results}

\subsection{Effect of Fenitrothion on Cell Proliferation}

We exposed two types of human cell lines, epithelial (Hep-2) and mammary (MDAMB-231), to different concentrations of our molecule of interest. The entry into apoptosis of cells or their death by necrosis is reflected by a slowdown in the metabolic activity. The MTT test measures this drop in the metabolic activity.

The cytotoxic effect of Fenitrothion on cell lines (Hep-2 and MDA-MB-231) was measured after $24 \mathrm{~h}$ of exposure to different concentrations $(0,50,100,200,400 \mu \mathrm{M})$.

The results presented in Figure 1 show that the cytotoxic effect of Fenitrothion on the cells increased in a dose dependent manner. However, it is much more remarkable in the Hep-2 cell line than in the MDA-MB-231 line. Indeed, the cytotoxicity percentages for the largest dose are $55.653 \pm 3.455 \%$ and $26.316 \pm 1.058 \%$ respectively after $24 \mathrm{~h}$ of exposure with an $\mathrm{IC}_{50}$ determined only for the Hep2 line, equal to $200.577 \mu \mathrm{M}$.

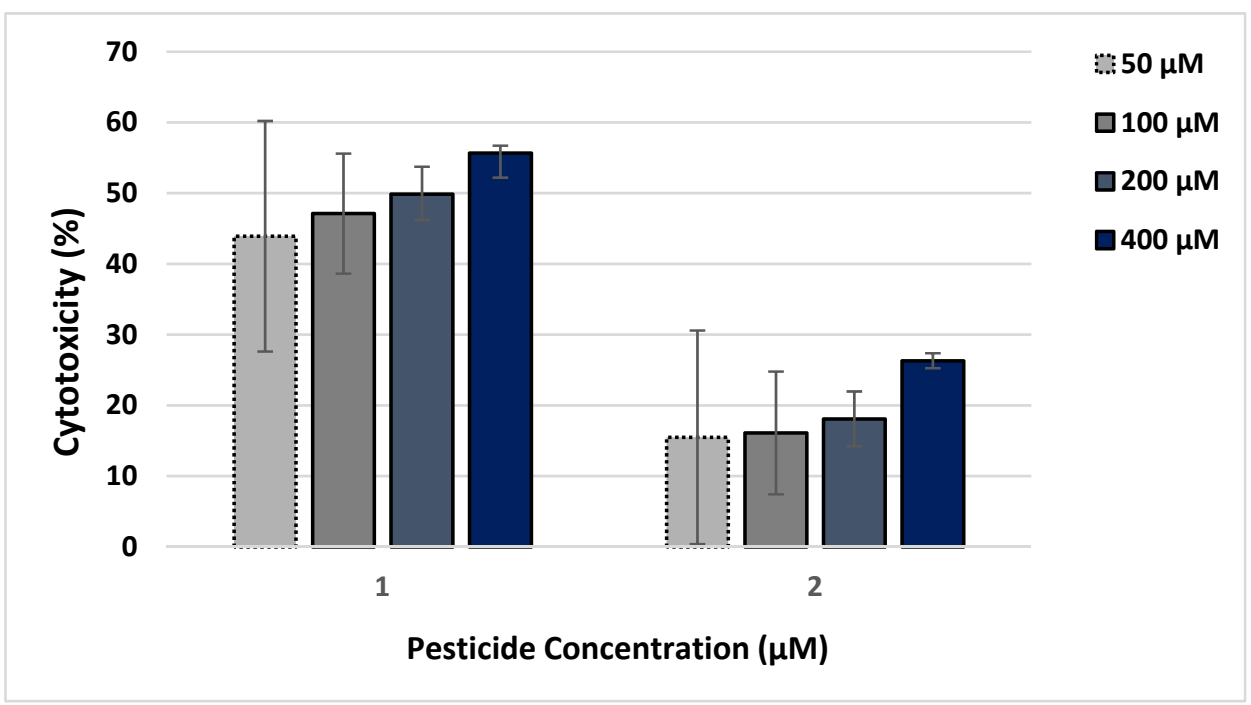

Figure 1. Cytotoxic effect of different concentrations of Fenitrothion on the cell lines Hep-2 and MDA-MB-231.

The cytotoxic effect of Fenitrothion on cell lines (Hep-2 and MDA-MB-231) was measured after $24 \mathrm{~h}$ of exposure to different pesticide concentrations $(0,50,100,200$, and $400 \mu \mathrm{M})$ with the MTT test. The results show that the cytotoxicity percentages for the largest dose are $55.653 \pm 3.455 \%$ and $26.316 \pm 1.058 \%$, respectively on Hep-2 and MDA- 
MB-231 after $24 \mathrm{~h}$ of exposure with an $\mathrm{IC}_{50}$ determined only for the Hep2 line equal to 200.577 Mm. All tests were performed for two independent experiments.

\subsection{Genotoxicity Assessment}

The genotoxicity of Fenitrothion was investigated with the bacterial VITOTOX ${ }^{\circledR}$ assay. It can be seen in Figure 2 that there was no increased light emission in both Cytox and Genox strains for any of the tested doses of Fenitrothion. This was noticed in the absence and the presence of S9 mix (S/N ratios were approximately "1"). This means that no cytotoxic or genotoxic effect was observed in the VITOTOX ${ }^{\circledR}$ assay of the tested concentrations of Fenitrothion.
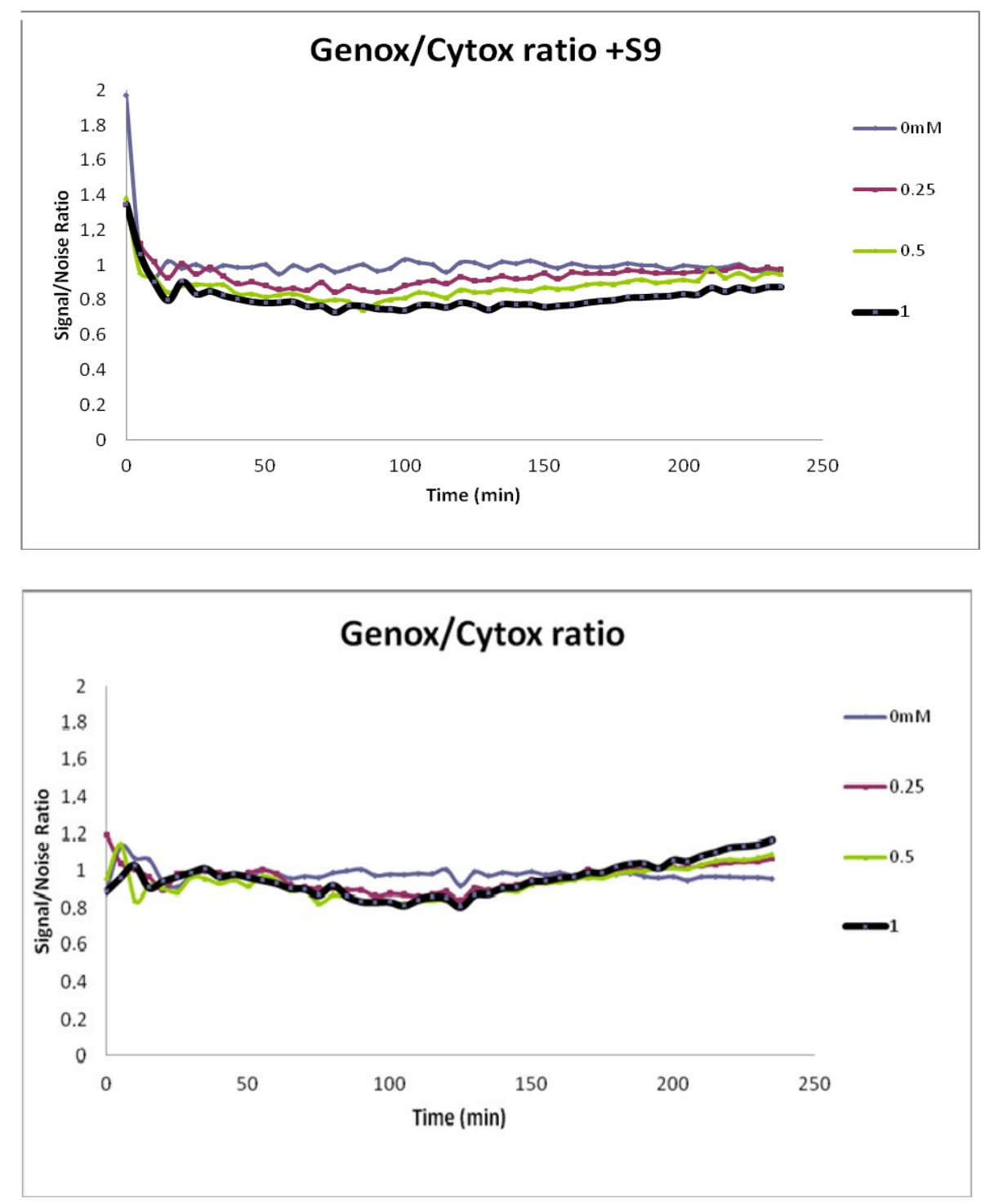

Figure 2. Findings of the VITOTOX ${ }^{\circledR}$ test for both bacterial strains (Genox and Cytox) exposed to different concentrations of Fenitrothion in the presence and absence of $\mathrm{S} 9 \mathrm{mix}$.

The genotoxicity of Fenitrothion was investigated with the bacterial VITOTOX ${ }^{\circledR}$ assay. It can be seen that there was no increased light emission in both Cytox and Genox strains for any of the tested doses of Fenitrothion, both in the absence or presence of S9 mix (S/N ratios were approximately " 1 "). 


\subsection{Estrogenic Activity Assessment}

The estrogenic activity of pure Fenitrothion was evaluated by measuring the transcriptional activation of $\mathrm{hER} \alpha$; so, co-transformed yeast cells with a $\mathrm{hER} \alpha$-expressing vector and a $\beta$-galactosidase reporter vector, were used [16]. Figure 3 displays the dose-response estrogenic activity of the E2 reference molecule, and that of Fenitrothion. All the measured activities were normalized to the E2 maximal activity value. It is worth mentioning that an increase of Fenitrothion molar concentration, from 4.5 to $18 \mathrm{mmol} / \mathrm{L}$, corresponding to a mass concentration of 1.25 and $5 \mathrm{~g} / \mathrm{L}$, results in a large and significant increase up to $32 \%$ of the observed maximal E2 activity. This relative estrogenic activity of $32 \%$ fits with a concentration of estrogens, expressed in E2 equivalents, of $1.35 \times 10^{-9} \mathrm{~mol} / \mathrm{L}$. Our results clearly show that the use of this insecticide can induce gene expression through $h E R \alpha$ transactivation and can cause adverse effects on human and animal health.
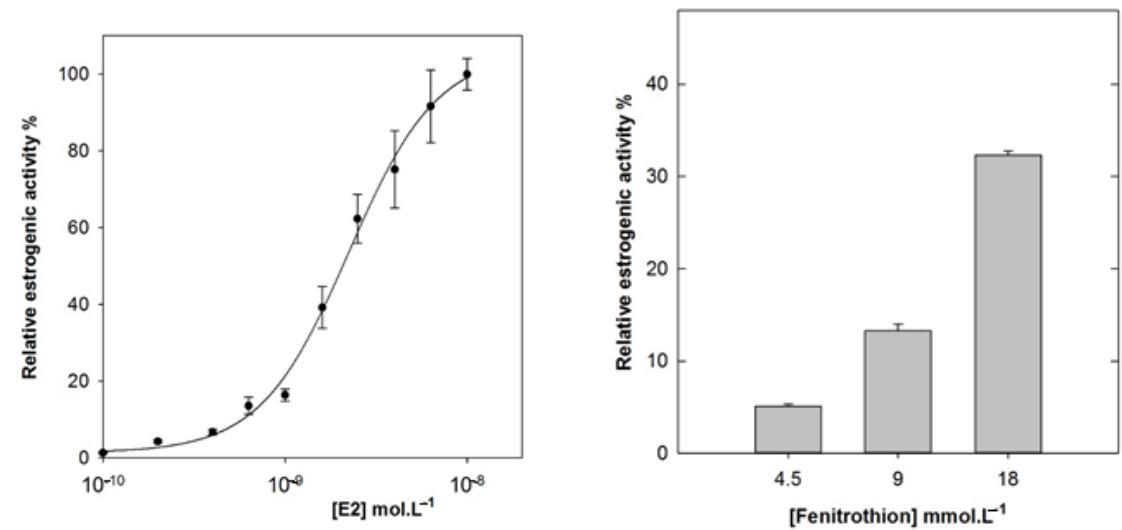

Figure 3. Estrogenic activity of the E2 reference molecule and that of Fenitrothion determined with the yeast estrogen screen (YES) assay.

The estrogenic activity of pure Fenitrothion was evaluated by measuring the transcriptional activation of $\mathrm{hER} \alpha$; so, co-transformed yeast cells with a $\mathrm{hER} \alpha$-expressing vector and a $\beta$-galactosidase reporter vector, were used. All the measured activities have been normalized to the E2 maximal activity value. Results show a relative estrogenic activity of $32 \%$ fits with a concentration of estrogens, expressed in E2 equivalents, of $1.35 \times 10^{-9} \mathrm{~mol} / \mathrm{L}$.

\subsection{Ecotoxicological Assessment}

When investigating the acute toxicity of Fenitrothion we used two species belonging to two different trophic levels. On the one hand, the freshwater crustacean Daphnia magna was chosen as the representative of consumers. On the other hand, the luminescent marine bacterium Vibrio fischeri was selected as the representative of decomposers.

\subsubsection{Daphnia Magna Assay}

In Daphnia magna's immobilization test, the acute toxicity endpoints $\left(\mathrm{EC}_{50}\right)$ after $48 \mathrm{~h}$ exposure of the target, Fenitrothion ranged from 55.3 to $79.8 \%$ (Table 1).

Table 1. Median values concentrations $\left(\mathrm{EC}_{50}\right)$ and toxic units (TU) values of Fenitrothion tested to Daphnia magna in 24, $48 \mathrm{~h}$ and towards Vibrio fischeri after 15 and $30 \mathrm{~min}$ exposure time (Test endpoint, bioluminescence).

\begin{tabular}{|c|c|c|c|c|c|c|}
\hline \multirow{3}{*}{ Compound } & \multicolumn{6}{|c|}{ Bioindicators } \\
\hline & \multicolumn{3}{|c|}{$\begin{array}{l}\text { Daphnia magna } \\
\mathrm{EC}_{50}\left(\mathrm{mgL}^{-1}\right)\end{array}$} & \multicolumn{3}{|c|}{$\begin{array}{l}\text { Vibrio fischeri } \\
\mathrm{EC}_{50}\left(\mathrm{mgL}^{-1}\right)\end{array}$} \\
\hline & $24 \mathrm{~h}$ & $48 \mathrm{~h}$ & TU & $15 \mathrm{~min}$ & $30 \mathrm{~min}$ & TU \\
\hline Fenitrothion & 79.8 & 55.3 & $1.26-1.80$ & 21.61 & 10.29 & $4.62-9.71$ \\
\hline
\end{tabular}


In Daphnia magna's immobilization test, the acute toxicity endpoints $\left(\mathrm{EC}_{50}\right)$ after $48 \mathrm{~h}$ exposure for the target Fenitrothion ranged from 55.3 to $79.8 \%$ (after $24 \mathrm{~h}$ ). In the Vibrio fischeri bioluminescence test, the $\mathrm{EC}_{50}$ value was calculated after $15 \mathrm{~min}$ and also after 30 min exposure to Fenitrothion the value was in the range 10.29-21.61\%.

In the case of a 48-hour exposure, the obtained value of the mean $48 \mathrm{~h}$ for $\mathrm{EC}_{50}$ was $55.3 \%$. As has been shown in this work Daphnia magna immobilization at increasing Fenitrothion concentrations was monitored. According to these results, it appears that the Fenitrothion mechanism of toxicity to D. magna depends on the concentration of the compound. The higher the concentration, the higher the toxicity rate. From the immobilization test, a toxic effect was observed for the Fenitrothion. This toxic effect was displayed within the concentration studied range.

As it was indicated, growth inhibition increased with the increasing of the Fenitrothion concentration. The toxicity of Fenitrothion, as it was expected, increased with the exposure time in D. magna; after $48 \mathrm{~h}$ the number of immobile D. magna had approximately doubled compared to that measured after $24 \mathrm{~h}$.

\subsubsection{Vibrio fischeri Assay}

In the Vibrio fischeri bioluminescence test, the $\mathrm{EC}_{50}$ value was calculated after $15 \mathrm{~min}$ and also after a 30 minute-exposure to Fenitrothion; it was in the range 10.29 to $21.61 \%$, as shown in Table 1. Fenitrothion, therefore, was considered to be toxic to Vibrio fischeri. There was little change in toxicity after 15 and 30 min of exposure.

Acute toxicity of Fenitrothion was thus observed. The value of $\mathrm{EC}_{50}$ was calculated after exposing the algae for $15 \mathrm{~min}$ and for $30 \mathrm{~min}$. The results of ecotoxicity of Fenitrothion on Vibrio fischeri differs depending on the exposure time. The estimated ecotoxic effect on $V$. fischeri exceeds $50 \%$ after 15 min of exposure time. When comparing the values that could be calculated from $\mathrm{EC}_{50}$ for $15 \mathrm{~min}$ and $30 \mathrm{~min}$, it is observed that there was a significant inhibition. The observed toxicity at $15 \mathrm{~min}$ showed that this type of organism is resistant during the first $5 \mathrm{~min}$.

\section{Discussion}

Despite their beneficial effects, pesticides have a harmful impact on humans and on the quality of the environment and foods [21,22]. Organophosphate insecticides are among the most widely used pesticides in Tunisia and the rate of poisoning by these pesticides represents $11 \%$ of all acute poisonings according to the Toxicology Reference Center in Tunis (center of urgent medical assistance and resuscitation CAMUR) [23]. Fenitrothion is an organophosphate pesticide which is used as a study molecule in our work for several reasons.

This insecticide is not only toxic to the target for which it has been developed but also to other non-target organisms including humans and the aquatic organisms.

Human exposure to this chemical can enhance the development of serious pathologies affecting the nervous system [6], the immune system [7] and the reproductive system [8].

Several in vitro studies have shown the cytotoxic [13] and genotoxic [24] effect of Fenitrothion.

This corroborates the results of our study, which has a major objective, the investigation of the effects of Fenitrothion on the 2 cell lines Hep-2 and MDA-MB-231.

Our results showed that Fenitrothion affects the metabolism of Hep-2 cells as well as the MDA-MB-231 cells, thus resulting in an increased dose-dependent cytotoxicity. This confirms the work of Li and Zhang [25], who demonstrated that the cytotoxic effect of an organophosphate pesticide on the multiplication of FG-9307 cells is dose-dependent. Our results show that the antiproliferative activity of Fenitrothion is found to be more important against Hep-2 cells than against MDA-MB-231 cells. Thus, we can conclude that the cytotoxic effect of pesticides depends on the cell type used [26]. 
Exposure of different cell lines to Fenitrothion can affect their cell proliferation. This biochemical reaction, among others, can be due to a direct interaction of this organophosphate pesticide with the glucocorticoid receptors, as in the case of MDA-MB-231 cells [27].

The cytotoxicity of Fenitrothion may also result from its ability to interact with the macromolecules and the cellular structures. Moreover, it proved to be able to disrupt several cellular functions. In fact, malformations of the mitochondrial structure (destruction of mitochondria by loss of ridges) were described by Adamski et al. [28].

Biochemical alterations in lipids, in proteins and in the DNA/RNA structures were demonstrated by Ukpebor et al. [24]. Likewise, the ability of Fenitrothion to generate oxidative damage through lipid peroxidation [13], the production of reactive oxygen species [29] and the disruption of the function of anti-oxidant enzymes [13] were also demonstrated in human cancer cells.

The genotoxicity assessment of Fenitrothion was performed using the bacterial VITOTOX ${ }^{\circledR}$ assay. It is a quick and simple genotoxicity screening assay which was shown to be effective in detecting chemical compounds that can cause genetic damage [15]. In the VITOTOX ${ }^{\circledR}$ test, no evidence of a cytotoxic or genotoxic activity was observed at the tested doses of Fenitrothion. Similar to our findings, Fenitrothion was found to be non-mutagenic and non-clastogenic in yeasts and rats [30].

Several other studies have reported that the cytotoxicity induced by Fenitrothion against breast cancer cells may also result from its binding to the estrogen receptor. It can function as an endocrine disruptor [31]. This falls within the scope of our third objective in this study, namely in the determination of the estrogenic activity of Fenitrothion using the YES assay. This bio-tool is widely used for monitoring pesticides which disrupt the estrogenic function. Findings from this bioassay confirm that Fenitrothion exhibits an estrogenic response in exposed yeasts. Our findings corroborate the previous studies reporting the possible environmental estrogenic and anti-estrogenic activities of Fenitrothion in human breast cancer MCF-7 cells [31].

Once present in the environment, Fenitrothion can have harmful impacts on both our flora and fauna - that is why it is mandatory to evaluate its ecotoxicological effects. The acute toxicity of Fenitrothion was investigated using a battery of two ecotoxicological tests: Daphnia magna and Vibrio fischeri tests. Both bioassays revealed that Fenitrothion possessed acute toxic effects for both target organisms ( $V$. fischeri and D. magna), and these effects were dose-dependent. Several studies have underlined the ecotoxic effect of Fenitrothion for the D. magna bioindicator [32] but very few studies have evaluated the toxicity of Fenitrothion in particular concerning the bacterium $V$. fischeri [33] and concerning bacteria in general. Consequently, our study is complementary to the previously performed biochemical studies.

For instance, in this study, the $\mathrm{LC}_{50}(48 \mathrm{~h})$ value for Fenitrothion was higher than that reported by [34] and [35]. The toxicity of Fenitrothion may be related to the numbers of P, S and $\mathrm{Cl}$ in the composition of each agricultural chemical [34,35].

It is worth mentioning that crustaceans, whose physiology presents many analogies to that of insects, are particularly sensitive to insecticides [36].

Many studies have underlined the acute and chronic toxicity of this compound towards fish and crustaceans [37,38] but also towards microalgae [39]. Other authors [40] have reported different values than those obtained in our study using the Microtox ${ }^{\mathrm{TM}}$ system. This is probably related to the variations in the cell suspension and the problems of reproducibility (within one laboratory and also between laboratories).

The toxicity assessment using: ecotoxicity, cytotoxicity and genotoxicity tests as well as the application of new molecular approaches, contributes to the evaluation of the potential ecotoxic effect of the pesticide at different levels of biological organization. These results encourage international commissions to move towards replacement and/or bioremediation procedures for this insecticide as is the case with Chlorpyrifos because of its confirmed neurotoxicity [41,42]. 
Likewise, biological control has paved the way for several molecules, active materials and organisms to be effective and ensure the role of insecticides. We can take the example of essential oils and their potential in the biological fight against the white fly Bemisia tabaci Genn [43].

The combination of active substances with different modes of action, and leading to synergy, is a promising and still under-exploited path. The objective sought in perspective is to increase the effectiveness of the treatment while reducing the doses of the active substances used. This is why we have already started a study on a possible synergy of action between Fenitrothion and a vertebrate antimicrobial peptide (results not shown). Indeed, antimicrobial peptides are produced by living organisms and offer strong possibilities in agriculture because new compounds can be developed on the basis of natural structures with improved properties of activity, specificity, biodegradability and toxicity [44].

\section{Conclusions}

In our work, we investigated the effect of an organophosphate pesticide, Fenitrothion, either in vitro or in vivo on different models. The results revealed an antiproliferative effect of the pesticide which depends both on the dose and on the cell line used. In addition, a significant estrogenic effect was determined during the YES test on yeasts, which may point to the mechanism of action of the pesticide on cells. The VITOTOX ${ }^{\circledR}$ test did not reveal any genotoxicity, but this in no way diminishes the toxicity of this insecticide. Indeed, the toxicity data helped in assessing the risk posed by Fenitrothion to aquatic biota. In fact, the acute toxicity of fenitrothion against two different aquatic species has proven to be very obvious. These results prompt us to look for other less harmful and more effective molecules against pests that can replace this kind of chemically synthesized pesticide. Indeed, in perspectives we are studying the effect of the mixture between Fenitrothion and an antimicrobial peptide on butyryl cholinesterase inhibition activity and the possibility of substitution of the pesticide by a natural molecule.

Author Contributions: Conceptualization, A.B., N.M. and E.N.; methodology, A.B., N.M., E.N., S.B. and V.L.T. (Véronique Le Tilly); software, A.B., N.M., E.N. and S.B.; formal analysis, A.B., N.M., E.N. and S.B.; investigation, A.B., N.M. and E.N.; data curation, A.B., N.M., E.N., V.L.T. (Véronique Le Tilly) and G.D.B.; writing-original draft, A.B., N.M. and E.N.; validation, R.A. and L.V.; resources, L.V., H.B.M. and N.H.K.; writing-review and editing, L.V., G.D.B., V.L.T. (Vincenzo Lo Turco), H.B.M. and N.H.K.; visualization, L.V., H.B.M. and N.H.K.; supervision, L.V., G.D.B., H.B.M. and N.H.K.; project administration, H.B.M. and N.H.K.; funding acquisition, H.B.M. and N.H.K. All authors have read and agreed to the published version of the manuscript.

Funding: This research received no external funding.

Institutional Review Board Statement: Not applicable.

Informed Consent Statement: Not applicable.

Conflicts of Interest: The authors declare no conflict of interest.

\section{References}

1. Hreljac, I.; Zajc, I.; Lah, T.; Filipič, M. Effects of model organophosphorous pesticides on DNA damage and proliferation of HepG2 cells. Environ. Mol. Mutagen. 2008, 49, 360-367. [CrossRef] [PubMed]

2. Lavarías, S.; García, C.F. Acute toxicity of organophosphate fenitrothion on biomarkers in prawn Palaemonetes argentinus (Crustacea: Palaemonidae). Environ. Monit. Assess. 2015, 187, 65. [CrossRef] [PubMed]

3. Delatte, H.; Paupy, C.; Dehecq, J.; Thiria, J.; Failloux, A.; Fontenille, D. Aedes albopictus, vecteur des virus du chikungunya et de la dengue à la Réunion: Biologie et contrôle. Parasite 2008, 15, 3-13. [CrossRef] [PubMed]

4. Leboulanger, C.; Schwartz, C.; Somville, P.; Diallo, A.O.; Pagano, M. Sensitivity of Two Mesocyclops (Crustacea, Copepoda, Cyclopidae), from Tropical and Temperate Origins, to the Herbicides, Diuron and Paraquat, and the Insecticides, Temephos and Fenitrothion. Bull. Environ. Contam. Toxicol. 2011, 87, 487-493. [CrossRef] [PubMed]

5. Baldi, I.; Cordier, S.; Coumoul, X.; Elbaz, A.; Gamet-Payrastre, L.; Lebailly, P.; Multigner, L.; Rahmani, R.; Spinosi, J.; van Maele-Fabry, G. Pesticides: Effets sur la SAnté. [Rapport de Recherche]; Institut National de la Santé et de la Recherche Médicale (INSERM): Paris, France, 2013. 
6. Cherin, P.; Voronska, E.; Fraoucene, N.; De Jaeger, C. Toxicité aiguë des pesticides chez l’homme. Médecine Longévité 2012, 4, 68-74. [CrossRef]

7. Nakashima, K.; Yoshimura, T.; Mori, H.; Kawaguchi, M.; Adachi, S.; Nakao, T.; Yamazaki, F. Effects of pesticides on cytokines production by human peripheral blood mononuclear cells-fenitrothion and glyphosate. Jpn. J. Toxicol. 2002, 15, 159-165.

8. Kamijima, M.; Hibi, H.; Gotoh, M.; Taki, K.-I.; Saito, I.; Wang, H.; Itohara, S.; Yamada, T.; Ichihara, G.; Shibata, E.; et al. A Survey of Semen Indices in Insecticide Sprayers. J. Occup. Health 2004, 46, 109-118. [CrossRef]

9. Ghorbel, A.; AREF, H.L.; Darouiche, M.H.; Nouri, N.M.; Masmoudi, M.L.; Akrout, F.M. Estimation du niveau de connaissance et Analyse toxicologique chez des manipulateurs de pesticides organophosphorés exposés au Fénitrothion dans la région de Sfax, en Tunisie. IJISR 2015, 25, 199-211.

10. Yurdakok-Dikmen, B.; Baydan, E.; Okur, H.; Gurcan, I.S. Cytotoxic effects of etephon and maleic hydrazide in Vero, Hep2, HepG2 cells. Drug Chem. Toxicol. 2013, 37, 459-465. [CrossRef]

11. Gorphe, P. A comprehensive review of Hep-2 cell line in translational research for laryngeal cancer. Am. J. Cancer Res. 2019, 9, 644-649.

12. Mohammed, F.; Rashid-Doubell, F.; Taha, S.; Cassidy, S.; Fredericks, S. Effects of curcumin complexes on MDA-MB-231 breast cancer cell proliferation. Int. J. Oncol. 2020, 57, 445-455. [CrossRef] [PubMed]

13. Ilboudo, S.; Fouche, E.; Rizzati, V.; Toé, A.M.; Gamet-Payrastre, L.; Guissou, P.I. In vitro impact of five pesticides alone or in combination on human intestinal cell line Caco-2. Toxicol. Rep. 2014, 1, 474-489. [CrossRef]

14. Ma, M.; Chen, C.; Yang, G.; Li, Y.; Chen, Z.; Qian, Y. Combined cytotoxic effects of pesticide mixtures present in the Chinese diet on human hepatocarcinoma cell line. Chemosphere 2016, 159, 256-266. [CrossRef] [PubMed]

15. Verschaeve, L.; Van Gompel, J.; Thilemans, L.; Regniers, L.; Vanparys, P.; Van der Lelie, D. VITOTOX ${ }^{\circledR}$ bacterial genotoxicity and toxicity test for the rapid screening of chemicals. Environ. Mol. Mutagen. 1999, 33, 240-248. [CrossRef]

16. Routledge, E.J.; Sumpter, J.P. Estrogenic activity of surfactants and some of their degradation products assessed using a recombinant yeast screen. Environ. Toxicol. Chem. 1996, 15, 241-248. [CrossRef]

17. Le Grand, A.; Bouter, A.; Couturier, A.; Mulner-Lorillon, O.; LE Goff, X.; Chesnel, F.; Sire, O.; Le Tilly, V. Investigation of the functional properties and subcellular localization of alpha human and rainbow trout estrogen receptors within a unique yeast cellular context. J. Steroid Biochem. Mol. Biol. 2015, 149, 17-26. [CrossRef] [PubMed]

18. Miller, J.H. Experiments in Molecular Genetics; Cold Spring Harbor Laboratory Press: Huntington, NY, USA, 1972.

19. Molins-Delgado, D.; Cruz, S.D.; Barceló, D. Ecological risk assessment associated to the removal of endocrine-disrupting parabens and benzophenone-4 in wastewater treatment. J. Hazard. Mater. 2016, 310, 143-151. [CrossRef] [PubMed]

20. Tamura, I.; Yasuda, Y.; Kagota, K.-I.; Yoneda, S.; Nakada, N.; Kumar, V.; Kameda, Y.; Kimura, K.; Tatarazako, N.; Yamamoto, H. Contribution of pharmaceuticals and personal care products (PPCPs) to whole toxicity of water samples collected in effluentdominated urban streams. Ecotoxicol. Environ. Saf. 2017, 144, 338-350. [CrossRef] [PubMed]

21. Di Bella, G.; Potortì, A.G.; Ben Tekaya, A.; Beltifa, A.; Ben Mansour, H.; Sajia, E.; Bartolomeo, G.; Naccari, C.; Dugo, G.; Turco, V.L. Organic contamination of Italian and Tunisian culinary herbs and spices. J. Environ. Sci. Health Part B 2019, 54, 345-356. [CrossRef]

22. Jebara, A.; Turco, V.L.; Potortì, A.G.; Bartolomeo, G.; Ben Mansour, H.; Di Bella, G. Organic pollutants in marine samples from Tunisian coast: Occurrence and associated human health risks. Environ. Pollut. 2020, 271, 116266. [CrossRef]

23. Eddleston, M.; Buckley, N.; Eyer, P.; Dawson, A. Management of acute organophosphorus pesticide poisoning. Lancet 2008, 371, 597-607. [CrossRef]

24. Ukpebor, J.; Llabjani, V.; Martin, F.L.; Halsall, C.J. Sublethal genotoxicity and cell alterations by organophosphorus pesticides in MCF-7 cells: Implications for environmentally relevant concentrations. Environ. Toxicol. Chem. 2010, 30, 632-639. [CrossRef]

25. Li, H.; Zhang, S. In vitro cytotoxicity of the organophosphorus pesticide parathion to FG-9307 cells. Toxicol. In Vitro 2001, 15, 643-647. [CrossRef]

26. Dellai, A.; Dridi, D.; Sakouhi, S.; Robert, J.; Djelal, H.; Mosrati, R.; Cherif, A.; Ben Mansour, H. Cytotoxic effect of chlorpyrifos ethyl and its degradation derivatives by Pseudomonas peli strain isolated from the Oued Hamdoun River (Tunisia). Toxicol. Ind. Health 2013, 32, 707-713. [CrossRef]

27. Nasri, E.; Machreki, M.; Beltifa, A.; Aroui, S.; Ghorbel, A.; Saad, A.; Feriani, A.; Borgi, M.A.; Ghazouani, L.; Sire, O.; et al. Cytotoxic effects of seven Tunisian hospital wastewaters on the proliferation of human breast cancer cell line MDA-231: Correlation with their chemical characterization. Environ. Sci. Pollut. Res. 2017, 24, 20422-20428. [CrossRef]

28. Adamski, Z.; Fila, K.; Maekowiak, J.; Ziemnicki, K. Fenitrothion-induced cell malformations in vitro in Spodoptera exigua cell line UCR-Se-1. Biol. Lett. 2005, 42, 41-47.

29. Livingstone, D. Contaminant-stimulated Reactive Oxygen Species Production and Oxidative Damage in Aquatic Organisms. Mar. Pollut. Bull. 2001, 42, 656-666. [CrossRef]

30. Yadav, A.; Vashishat, R.; Kakar, S. Testing of endosulfan and fenitrothion for genotoxicity in Saccharomyces cerevisiae. Mutat. Res. Lett. 1982, 105, 403-407. [CrossRef]

31. Okubo, T.; Yokoyama, Y.; Kano, K.; Soya, Y.; Kano, I. Estimation of Estrogenic and Antiestrogenic Activities of Selected Pesticides by MCF-7 Cell Proliferation Assay. Arch. Environ. Contam. Toxicol. 2004, 46, 445-453. [CrossRef] [PubMed]

32. Pergal, M.V.; Kodranov, I.D.; Pergal, M.M.; Gašić, U.; Stanković, D.M.; Petković, B.B.; Manojlović, D.D. Degradation Products, Mineralization, and Toxicity Assessment of Pesticides Malathion and Fenitrothion. Water Air Soil Pollut. 2020, 231, 433. [CrossRef] 
33. Amorós, I.; Connon, R.; Garelick, H.; Alonso, J.; Carrasco, J. An assessment of the toxicity of some pesticides and their metabolites affecting a natural aquatic environment using the Microtox ${ }^{\mathrm{TM}}$ system. Water Sci. Technol. 2000, 42, 19-24. [CrossRef]

34. Hatakeyama, S.; Sugaya, Y. A freshwater shrimp (Paratya compressa improvisa) as a sensitive test organism to pesticides. Environ. Pollut. 1989, 59, 325-336. [CrossRef]

35. Kikuchi, M.; Sasaki, Y.; Wakabayashi, M. Screening of Organophosphate Insecticide Pollution in Water by Using Daphnia magna. Ecotoxicol. Environ. Saf. 2000, 47, 239-245. [CrossRef]

36. Insecticides Mode of Action in Relation to Their Toxicity to Non-Target Organisms. J. Environ. Anal. Toxicol. 2012, s4. [CrossRef]

37. Liu, Y.; Tam, N.F.Y.; Guan, Y.; Yasojima, M.; Zhou, J.; Gao, B. Acute toxicity of nonylphenols and bisphenol A to the embryonic development of the abalone Haliotis diversicolor supertexta. Ecotoxicology 2011, 20, 1233-1245. [CrossRef]

38. Toumi, H.; Boumaiza, M.; Millet, M.; Radetski, C.M.; Camara, B.I.; Felten, V.; Masfaraud, J.-F.; Férard, J.-F. Combined acute ecotoxicity of malathion and deltamethrin to Daphnia magna (Crustacea, Cladocera): Comparison of different data analysis approaches. Environ. Sci. Pollut. Res. 2018, 25, 17781-17788. [CrossRef]

39. Liu, Y.; Guan, Y.; Gao, Q.; Tam, N.F.Y.; Zhu, W. Cellular responses, biodegradation and bioaccumulation of endocrine disrupting chemicals in marine diatom Navicula incerta. Chemosphere 2010, 80, 592-599. [CrossRef]

40. Ruiz, M.J.; López-Jaramillo, L.; Redondo, M.J.; Font, G. Toxicity assessment of pesticides using the microtox test: Application to environmental samples. Bull. Environ. Contam. Toxicol. 1997, 59, 619-625. [CrossRef]

41. Suman, S.; Singh, T.; Swayamprabha, S.; Singh, S. Biodegradation of Pesticide Chlorpyrifos by Bacteria Staphylococcus aureus (Accession no. CP023500.1) Isolated from Agricultural Soil. J. Ecophysiol. Occup. Health 2020, 20, 21-26. [CrossRef]

42. Dixit, S.; Zia, M.K.; Siddiqui, T.; Ahsan, H.; Khan, F.H. Interaction of organophosphate pesticide chlorpyrifos with alpha2-macroglobulin: Biophysical and molecular docking approach. J. Immunoass. Immunochem. 2020, 42, 138-153. [CrossRef] [PubMed]

43. Tia, V.E.; Lozano, P.; Menut, C.; Lozano, Y.F.; Martin, T.; Niamké, S.; Adima, A.A. Potentialité des huiles essentielles dans la lutte biologique contre la mouche blanche Bemisia tabaci Genn. Phytothérapie 2013, 11, 31-38. [CrossRef]

44. Montesinos, E.; Bardaji, E. Synthetic Antimicrobial Peptides as Agricultural Pesticides for Plant-Disease Control. Chem. Biodivers. 2008, 5, 1225-1237. [CrossRef] [PubMed] 